\title{
Training of advanced practice nurses in oncology for the best care: a systematic review
}

\author{
Formação de enfermeiros de prática avançada em oncologia \\ para o melhor cuidado: uma revisão sistemática \\ Capacitación de enfermeros de práctica avanzada en oncología \\ para un cuidado mejor: revisión sistemática
}

How to cite this article:

Schneider F, Kempfer SS, Backes VMS. Training of advanced practice nurses in oncology for the best care: a systematic review. Rev Esc Enferm USP. 2021;55:e03700. doi: https://doi.org/10.1590/S1980-220X2019043403700

\section{Franciane Schneider ${ }^{1}$ \\ Silvana Silveira Kempfer ${ }^{1}$ \\ Vânia Marli Schubert Backes² \\ 1 Universidade Federal de Santa Catarina, Programa de Pós-Graduação em Enfermagem, Florianópolis, SC, Brazil. \\ 2 Universidade Estadual de Maringá, Programa de Pós-Graduação em Enfermagem, Maringá, PR, Brazil.}

Corresponding author: Franciane Schneider Departamento de Enfermagem, Centro de Ciências da Saúde, Bloco I, sala 317, $3^{\circ}$ andar Campus Universitário, Trindade CEP 88040-900 - Florianópolis, SC, Brazil franciane_06@yahoo.com.br

\begin{abstract}
Objective: To search for evidence on the training of advanced practice nurses, through clinical practice and nursing care with cancer patients. Method: Systematic review, searching the databases: MEDLINE-PubMed, LILACS, Web of Science, Scopus, CINAHL and Cochrane CENTRAL. A manual search of the reference list and Google Scholar was also carried out. To assess the methodological quality of the studies, the following tools were used: Cochrane Collaboration Risk of Bias Tool (RoB 1) for randomized controlled trials and Risk of Bias in Non-randomized Studies of Interventions (ROBINS-I) for quasi-experimental studies. Results: A total of 12 experimental studies were identified. The main intervention identified in the studies was educational guidance. The studies showed improvement in pain control or other symptoms related to disease and/or treatment, satisfaction and improvement in the quality of life of cancer patients. Conclusion: It is observed that there are studies that demonstrate the value of advanced practice nursing in oncology, through differentiated clinical training and advanced professional performance. Registration number of the systematic review: CRD42018098906.
\end{abstract}

DESCRIPTORS

Oncology Nursing; Advanced Practice Nursing; Treatment Outcome; Evidence-Based Nursing; Review. 


\section{INTRODUCTION}

There is a growing interest in adopting practices capable of innovating and improving health systems to respond to problems arising from the population needs, especially with the increase in chronic diseases. Part of these problems is related to the health workforce, the lack of professionals, in addition to compatible training to provide qualified health care $^{(1)}$. Nowadays, one of the innovations on the agenda and with extensive discussions in health is advanced practice nursing (APN).

The APN originated in Canada and the United States of America (USA) more than 40 years ago. Since then, several countries have gradually structured this practice, through educational preparation, reformulation and/or creation of specific regulations, the definition of the role and forms of professional performance for expanded and excellent health $\operatorname{care}^{(2-3)}$.

According to the International Council of Nurses (ICN)(4), advanced practice nurses are the ones who have acquired the base of specialized knowledge, complex decision-making skills and clinical skills for an expanded practice, whose characteristics are shaped according to the context of each country and according to the different scenarios of existing practice, requiring educational preparation at an advanced level - the master's degree is recommended. It is also noted that in some countries, the APN had an educational training beyond the master's level, so that it was possible to expand the scope of its practice ${ }^{(5)}$.

There are different terminologies adopted to identify the advanced practice of nurses, however, the terms commonly used to refer to these qualified professionals are: nurse practitioner (NP) and clinical nurse specialist (CNS). The NP tends to be more involved in clinical care, has an expanded scope of clinical practice that gives them autonomy to coordinate diagnoses and prescribe treatments and/or medications. On the other hand, the CNS often has greater responsibility for non-clinical activities, such as education, leading improvements in the quality of care (development of clinical guidelines and protocols) and management of health services, in addition to providing highly complex and specialized care ${ }^{(6)}$.

International studies have showed the positive impact of the nurses' role in advanced practice in improving health outcomes with the patient, in the quality of care and in resolving the adversities of health systems ${ }^{(7)}$. Currently, more than 70 countries are interested in implementing advanced practice in nursing, just as there are different stages of development of their functions ${ }^{(6)}$. It is noteworthy that in Brazil the implementation of APN in Primary Care has been discussed with greater emphasis, as a response to the growing health needs of the population and difficulties in accessing human resources ${ }^{(8,9)}$, although there are different fields for professional performance.

The world estimate shows that, in 2018, there were 18.1 million new cases of cancer and 9.6 million deaths ${ }^{(10)}$. It is estimated for Brazil, in the 2020-2022 biennium, the occurrence of a total of 625 thousand new cases of cancer for each year ${ }^{(11)}$. According to these incidence and prevalence data, the importance of qualified professionals, with specific knowledge, skills and attitudes to work with this type of patients with complex care needs is evident, highlighting the implementation of APN in the oncology scenario ${ }^{(12)}$.

Some studies have evaluated the roles, responsibilities, standards of clinical practice and productivity of advanced practice nurses in oncology ${ }^{(13-15)}$, with the objective of obtaining data to fill the existing workforce gap in this field, due to the increase in the population diagnosed with cancer and its survivors ${ }^{(16)}$. Advanced practice nurses in oncology provide high quality care and its implementation solves the lack of professionals with specific skills for the care provided to this population ${ }^{(17-19)}$. However, it is observed that the performance of this professional becomes a challenge, due to the variability and complexity of the practice, added to the emergence of new and changing knowledge of the area in recent years. Currently, patients are diagnosed earlier and live longer. There are treatments with traditional chemotherapy, but genomics, as well as other omic sciences (transcriptomics/ proteomics/epigenomics/metabolomics/pharmacogenomics), along with bioinformatics and biomarkers, which make up the three interdisciplinary pillars of Personalized Medicine, have been determining the therapeutic choices with more accuracy and precision, especially in oncology. Like immunotherapy, which has become a first-line treatment for some types of cancer ${ }^{(20-21)}$. These technological advances continuously change the care for cancer patients, and consequently reflect on the role of the APN in oncology developed in the different care environments ${ }^{(21)}$.

Thus, the objective of this study is to seek evidence of the training of advanced practice nurses, through clinical practice and nursing care with cancer patients.

\section{METHOD}

\section{TYPE OF STUDY}

This is a systematic review guided by the recommendations of the Preferred Reporting Items for Systematic Reviews and Meta-Analyzes PRISMA Checklist ${ }^{(22)}$. The systematic review protocol was registered in the International Prospective Register of Systematic Reviews (PROSPERO), under number CRD42018098906 ${ }^{(23)}$.

\section{Data collection}

The guiding question of the review, elaborated based on the PICO strategy ${ }^{(24)}$, was: Does the training of advanced practice nurses result in better clinical performance and nursing care in cancer patients?

The electronic database search took place on the following bases: Medical Literature Analysis and Retrieval System Online (MEDLINE) - via the National Library of Medicine, National Institutes of Health (Pubmed), Latin American and Caribbean Literature in Health Sciences (LILACS), Institute for Scientific Information (ISI) Web of Knowledge - via Web of Science, Scopus, Cumulative Index to Nursing and Allied Health Literature (CINAHL-EBSCO) and Cochrane Central Register of Controlled Trials (CENTRAL). In addition, a manual search was performed in the reference list 
of the selected articles, in order not to lose evidence, and a search in the gray literature through Google Scholar. The following eligibility criteria were considered: experimental studies (randomized controlled trials and quasi-experiments) that demonstrated results of APN performance in the care of cancer patients. Studies published in full, in any language, with no time limit for the year of publication were included.

\section{SeARCH STRATEGY}

The descriptors were selected from the Medical Subject Headings Section (MeSH), Health Sciences Descriptors (DeCs) and CINAHL Subject Headings. The following search terms were used in MEDLINE (via Pubmed), and the strategy was adapted to other databases: ("oncology nursing” OR “oncology” AND "nursing” OR “oncology nursing”) AND ("advanced practice nursing” OR "advanced” AND "practice” AND "nursing” OR "advanced practice nursing" OR “nurse practitioners" OR "nurse” AND "practitioners" OR "nurse practitioners" OR "nurse clinicians" OR "nurse” AND "clinicians" OR "nurse clinicians” OR "education, nursing, graduate” OR “education” AND “nursing” AND "graduate" OR "graduate nursing education" OR "education" AND "nursing” AND "graduate” OR "education, nursing, graduate") AND ("treatment outcome" OR "treatment" AND "outcome" OR "treatment outcome" OR "evidencebased practice” OR "evidence-based” AND "practice” OR "evidence-based practice" OR "evidence” AND "based” AND "practice" OR "evidence based practice" OR "evidence-based nursing” OR “evidence-based” AND "nursing” OR “evidence-based nursing” OR "evidence” AND "based” AND "nursing” OR "evidence based nursing" OR "outcome assessment (health care)" OR "outcome” AND “assessment” AND "(health” AND “care)” OR “outcome assessment (health care)" OR ("outcome” AND “assessment" OR “outcome assessment" AND "delivery of health care" OR "delivery" AND "health" AND "care" OR "delivery of health care" OR "health" AND "care" OR "health care" OR "quality of health care" OR "quality" AND "health" AND "care" OR "quality of health care" OR ("patient outcome assessment" OR "patient" AND "outcome" AND "assessment" OR "patient outcome assessment” OR "patient satisfaction” OR "patient” AND "satisfaction" OR "patient satisfaction”).

After collection, data were organized using EndNote Web ${ }^{\circledR}$ software, which excluded duplicate studies. The search in electronic databases took place on July 15, 2018 and was updated on December 15, 2019.

\section{Study Selection}

In order to ensure the quality of the systematic review and avoid bias, studies were selected in two stages: 1. two researchers (F.S. and S.S.K.) individually examined the titles and abstracts of the articles that would possibly meet the inclusion criteria; 2 . the same researchers read the selected articles, individually and in full, and excluded those that did not meet the inclusion criteria. The cases of divergence among researchers, in any of the steps mentioned, followed by discussions for consensus. In the absence of an agreement, the third investigator (V.M.S.B) was involved in the decisionmaking process.

\section{Data collection PROCESS}

For data extraction a form was prepared for this study, which adopted the guidelines provided by the Cochrane Collaboration ${ }^{(25)}$ with regard to content and structure. This pre-established form included the following information: study identification (title, journal, year of publication, volume, number and authors), objectives and method (randomization method, concealment, number of randomized patients, description of loss of follow-up, inclusion and exclusion criteria, clinical characteristics, intervention in the experimental and control groups, data analysis and outcomes). Thus, it also comprises other information deemed relevant, such as: country and area/scenario of study development and professional training/qualification. Data collection took place independently by two researchers (F.S. and S.S.K.), for later validation and agreement. The third investigator (V.M.S.B) evaluated all the data collected for final decision.

Since most of the studies analyzed showed significant methodological differences, such as heterogeneous area of clinical practice and/or specialty, profile of participants, characteristics of interventions and clinical outcomes, the conduction of the meta-analysis was not feasible. Therefore, in this systematic review, one performed a qualitative synthesis for data presentation.

\section{RISK OF BIAS IN INDIVIDUAL STUDIES}

Regarding the evaluation of the methodological quality of the selected randomized clinical trials, the Cochrane Collaboration Risk of Bias Tool (RoB 1) ${ }^{(25)}$, was used, which assesses seven domains: I) randomization process (selection bias); II) Allocation sequence (selection bias); III) Blinding of the participants and the team involved (performance bias); IV) Blinding of outcome evaluators (detection bias); V) Incomplete outcomes (attrition bias); VI) Report of selective outcome (publication bias); VII) Other sources of bias. Based on these assessed domains, studies are classified as risk of low, high or uncertain bias ${ }^{(25)}$. Regarding quasi-experimental studies, the Risk of Bias in Non-randomized Studies of Interventions (ROBINS-I) tool ${ }^{(26)}$, was used, which assesses seven domains: confusion bias, selection bias of study participants, bias classification of interventions, bias due to deviations from the proposed interventions, information bias (missing), bias in measuring outcomes and bias in selective reporting of outcomes. The first two domains refer to the pre-intervention period, the third one is related to the intervention period and the last four domains are related to the post-intervention period ${ }^{(26)}$. In each item, studies were classified as low, moderate, serious or critical regarding risk of bias. Subsequently, the studies were generally classified as low (low risk in all domains), moderate (low or moderate risk in all domains), serious (serious risk in at least one domain) and critical (critical risk in at least one domain) a domain). Two researchers performed this process independently (F.S. 
and S.S.K.). Disagreements between the two reviewers were resolved by a third researcher (V.M.S.B).

For the graphical presentation of risk of bias from the studies, the The Cochrane Collaboration's Review Manager $5^{\circledR}$ (RevMan 5) was used for randomized controlled trials, in addition to Risk-of-bias VISualization ${ }^{\circledR}$ (Robvis) for quasi-experiments.

\section{RESULTS}

Figure 1 (Flow Diagram) details the process of identification, inclusion and exclusion of studies. A total of 12 experimental studies, 10 randomized clinical trials and two quasi-experiments were identified, with APN performance results in the care of cancer patients.
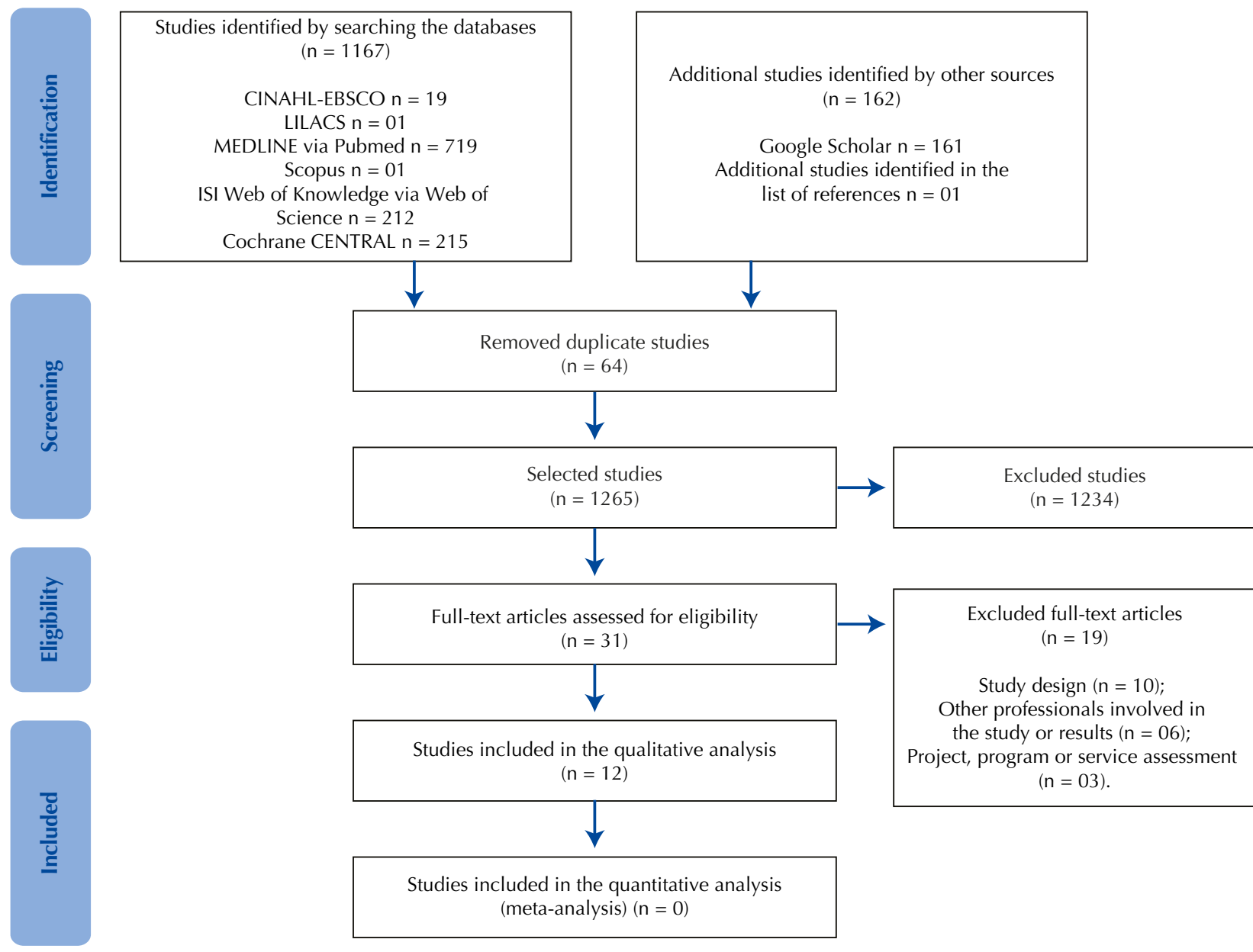

Figure 1 - Flowchart for the selection of articles in the systematic review.

The selected studies were published between 2000 and 2017, however, most studies (83.3\%) were published in the last 10 years and all in English. The USA published 75\% of the studies. England, the Netherlands and South Korea published $8.3 \%$ each. The settings of the studies were the following: chemotherapy treatment $(25 \%)$, palliative care
(16.7\%), gynecological cancer (16.7\%), breast cancer (8.3\%), lung cancer $(8.3 \%)$, pediatric oncology $(8.3 \%)$, cancer survivors $(8.3 \%)$ and home care (8.3\%). Chart 1 summarizes the descriptive characteristics of the experimental studies included in this systematic review. 
Chart 1 - Summary of characteristics of included studies - Florianopolis, SC, Brazil, 2019.

\begin{tabular}{|c|c|c|c|c|c|c|}
\hline \multicolumn{3}{|c|}{ CHARACTERISTICS OF THE STUDY } & \multicolumn{2}{|c|}{ POPULATION } & \multicolumn{2}{|c|}{ INTERVENTION } \\
\hline $\begin{array}{l}\text { Reference, } \\
\text { Country, } \\
\text { Journal } \\
\text { Area / Scenario }\end{array}$ & $\begin{array}{l}\text { Design / } \\
\text { Method }\end{array}$ & Objective & Total N & $\begin{array}{c}\text { Education / } \\
\text { Degree }\end{array}$ & $\mathrm{IG}^{*} / \mathrm{CG}^{+}$ & Main results \\
\hline $\begin{array}{l}\text { Bakitas M et al. } \\
\mathbf{2 0 0 9}^{(27)} \text {, } \\
\text { USA, } \\
\text { Journal of } \\
\text { the American } \\
\text { Medical } \\
\text { Association } \\
\text { Palliative care }\end{array}$ & $\begin{array}{l}\text { Randomized } \\
\text { Controlled } \\
\text { Clinical Trial } \\
\text { (parallel) }\end{array}$ & $\begin{array}{l}\text { To determine the } \\
\text { effect of a nursing } \\
\text { intervention } \\
\text { on quality of } \\
\text { life, symptoms } \\
\text { intensity, mood } \\
\text { and resources } \\
\text { used in patients } \\
\text { with advanced } \\
\text { cancer }\end{array}$ & 277 & $\mathrm{APN}^{\ddagger}$ & $\begin{array}{l}\text { Usual cancer care vs } \\
\text { psychoeducational } \\
\text { intervention conducted } \\
\text { by } \mathrm{APN}^{\ddagger} \text { (it consisted of } \\
4 \text { weekly educational } \\
\text { sessions and monthly } \\
\text { follow-up sessions until } \\
\text { death or completion of } \\
\text { the study) } \\
\mathrm{IG}^{*}: \mathrm{n}=143 \\
\mathrm{CG}^{+}: \mathrm{n}=134\end{array}$ & $\begin{array}{l}\text { Higher quality of life }(\mathrm{p}=0.02) \text {, } \\
\text { less depressed mood }(\mathrm{p}=0.02) \\
\text { and tendency to lesser intensity } \\
\text { of symptoms }(\mathrm{p}=0.06) \\
\text { Increased survival: } 5.5 \text { months } \\
\text { The median survival was } 14 \\
\text { months }(95 \% \mathrm{Cl}=[10.6-18.4]) \\
\text { for the intervention group and } \\
8.5 \text { months }(95 \% \mathrm{Cl}=[7.0- \\
11.1]) \text { for the usual treatment } \\
\text { group ( } \mathrm{p}=0.14)\end{array}$ \\
\hline $\begin{array}{l}\text { Cox CL et al. } \\
\text { 2016 }^{(28)}, \\
\text { USA, } \\
\text { Oncology } \\
\text { Nursing Forum } \\
\text { Pediatric } \\
\text { Oncology }\end{array}$ & $\begin{array}{l}\text { Randomized } \\
\text { Controlled } \\
\text { Clinical Trial } \\
\text { (parallel) }\end{array}$ & $\begin{array}{l}\text { To document } \\
\text { survivor tracking } \\
\text { costs according to } \\
\text { the care plan (with } \\
\text { or without) } \mathrm{APN}^{\ddagger} \\
\text { counseling }\end{array}$ & 411 & $\mathrm{APN}^{\ddagger}$ & $\begin{array}{l}\text { Sending a "survival care } \\
\text { plan" by mail, with APN" } \\
\text { telephone counseling } \\
\text { or care plan without } \\
\text { telephone counseling } \\
\mathrm{IG}^{*}: \mathrm{n}=205 \\
\mathrm{CG}^{+}: \mathrm{n}=206\end{array}$ & $\begin{array}{l}\text { The intervention motivated } \\
\text { the participation of patients } \\
\text { in the study of left ventricular } \\
\text { function by } 30 \% \text { when } \\
\text { compared to the control - } \\
\text { Increased screening } \\
\text { Adding APN }{ }^{\ddagger} \text { counseling to } \\
\text { a survival care plan can help } \\
\text { preserve heart health at little or } \\
\text { no cost per survivor }\end{array}$ \\
\hline $\begin{array}{l}\text { Dyar S et al. } \\
\mathbf{2 0 1 2}^{(29)} \text {, } \\
\text { USA, } \\
\text { Journal of } \\
\text { Palliative } \\
\text { Medicine } \\
\text { Palliative care }\end{array}$ & $\begin{array}{l}\text { Randomized } \\
\text { Controlled } \\
\text { Clinical Trial } \\
\text { (parallel) }\end{array}$ & $\begin{array}{l}\text { To evaluate the } \\
\text { results of quality } \\
\text { of life in advanced } \\
\text { cancer patients } \\
\text { who received } \\
\text { palliative care } \\
\text { interventions } \\
\text { based on } \\
\text { discussions with } \\
\mathrm{NP}^{\S}\end{array}$ & 26 & $N P^{\S}$ & $\begin{array}{l}\text { Standard treatment vs } \\
\text { Intervention by NP§ } \\
\text { (discussions about } \\
\text { hospice benefits, } \\
\text { discussions about wills } \\
\text { in life and advance } \\
\text { directives, along with } \\
\text { an assessment of quality } \\
\text { of life). } \\
\mathrm{IG}^{*}: \mathrm{n}=12 \\
\mathrm{CG}^{+}: \mathrm{n}=14\end{array}$ & $\begin{array}{l}\text { Statistically significant } \\
\text { improvements were observed } \\
\text { in the initial assessments in } \\
\text { the emotional }(p=0.0106) \\
\text { and mental }(p=0.02) \text { domains } \\
\text { of quality of life in the } \\
\text { intervention group } \\
\text { Patients found it helpful to } \\
\text { have the living will and policy } \\
\text { documents offered as part of } \\
\text { the NP§ intervention }\end{array}$ \\
\hline $\begin{array}{l}\text { Hudson MM } \\
\text { et al. } \\
\mathbf{2 0 1 4}{ }^{(30)} \text {, } \\
\text { USA and } \\
\text { Canada, } \\
\text { Journal of } \\
\text { Clinical } \\
\text { Oncology } \\
\text { Cancer } \\
\text { Survivors }\end{array}$ & $\begin{array}{l}\text { Randomized } \\
\text { Controlled } \\
\text { Clinical Trial } \\
\text { (parallel) }\end{array}$ & $\begin{array}{l}\text { To determine } \\
\text { whether adding } \\
\text { APN }^{\ddagger} \text { telephone } \\
\text { counseling to } \\
\text { a survival care } \\
\text { plan significantly } \\
\text { increases the } \\
\text { proportion of } \\
\text { survivors at risk } \\
\text { who complete } \\
\text { cardiomyopathy } \\
\text { screening }\end{array}$ & 472 & $\mathrm{APN}^{\ddagger}$ & $\begin{array}{l}\text { Standard care consisted } \\
\text { of a survival care plan } \\
\text { summarizing cancer } \\
\text { treatment and cardiac } \\
\text { health screening } \\
\text { recommendations. } \\
\text { The intervention } \\
\text { consisted of standard } \\
\text { treatment + } 2 \text { telephone } \\
\text { counseling sessions with } \\
\text { APN }^{\ddagger} \\
\mathrm{IG}^{*}: \mathrm{n}=238 \\
\mathrm{CG}^{+}: \mathrm{n}=234\end{array}$ & $\begin{array}{l}\text { 1-year follow-up: } 107(52.2 \%) \\
\text { of } 205 \text { survivors in the APN }{ }^{\ddagger} \\
\text { group completed screening } \\
\text { compared with } 46(22.3 \%) \text { of } \\
206 \text { survivors in the non-APN }{ }^{\ddagger} \\
\text { group } \\
\text { Survivors in the APN }{ }^{\ddagger} \text { group } \\
\text { were } 2 \text { times more likely to } \\
\text { complete the recommended } \\
\text { cardiomyopathy screening at } \\
2 \text { or } 5 \text { years of follow-up than } \\
\text { those in the control group } \\
\text { (RR=2.31; } 95 \% \text { Cl: } 1.74-3.07 \text {; } \\
\text { (p<0.001) } \\
\text { Survivors in the control } \\
\text { group were more likely to } \\
\text { relate the lack of medical } \\
\text { recommendation as a reason } \\
\text { for not completing the } \\
\text { cardiomyopathy screening } \\
\text { when compared to those in the } \\
\text { counseling group with APN }{ }^{\ddagger} \\
\text { (p=0.02) }\end{array}$ \\
\hline
\end{tabular}




\begin{tabular}{|c|c|c|c|c|c|c|}
\hline \multicolumn{3}{|c|}{ CHARACTERISTICS OF THE STUDY } & \multicolumn{2}{|c|}{ POPULATION } & \multicolumn{2}{|c|}{ INTERVENTION } \\
\hline $\begin{array}{l}\text { Reference, } \\
\text { Country, } \\
\text { Journal } \\
\text { Area / Scenario }\end{array}$ & $\begin{array}{l}\text { Design / } \\
\text { Method }\end{array}$ & Objective & Total $N$ & $\begin{array}{c}\text { Education / } \\
\text { Degree }\end{array}$ & $\mathrm{IG}^{*} / \mathrm{CG}^{+}$ & Main results \\
\hline $\begin{array}{l}\text { Kim MY } \\
\text { 2011 }^{(31)} \text {, } \\
\text { South Korea, } \\
\text { Clinical Journal } \\
\text { of Oncology } \\
\text { Nursing } \\
\text { Chemotherapy } \\
\text { Treatment }\end{array}$ & $\begin{array}{l}\text { Quasi- } \\
\text { experimental } \\
\text { study }\end{array}$ & $\begin{array}{l}\text { To demonstrate } \\
\text { the effect of CNS } \\
\text { oncological } \\
\text { interventions in } \\
\text { cancer patients } \\
\text { undergoing } \\
\text { chemotherapy }\end{array}$ & 112 & $\begin{array}{l}\text { APN }^{\ddagger} \\
\text { CNS } \|\end{array}$ & $\begin{array}{l}\text { Intervention: consisted } \\
\text { of patients who were } \\
\text { treated by an oncological } \\
\text { CNS" } \\
\text { Control: composed of } \\
\text { patients who were not } \\
\text { treated by CNS" } \\
\text { CNS" performance: } \\
\text { education, direct care, } \\
\text { counseling, research and } \\
\text { leadership } \\
\mathrm{IG}^{*}: \mathrm{n}=65 \\
\mathrm{CG}^{+}: \mathrm{n}=47\end{array}$ & $\begin{array}{l}\mathrm{CNS} \| \text { interventions decreased } \\
\text { pain by } 69 \% \text { and fatigue by } \\
77 \% \\
\text { There was an increase in } \\
\text { health-related quality of life, } \\
\text { being } 4.43 \text { times higher in the } \\
\text { intervention group ( } 95 \% \mathrm{Cl}= \\
[1.34-14.66] ; \mathrm{p}=0.02) \\
\text { Overall satisfaction with the } \\
\text { intervention group was } 0.2 \\
\text { times greater than the control } \\
\text { group }(95 \% \mathrm{Cl}=[0.07-0.57] \text {; } \\
\text { p<0.01) and satisfaction with } \\
\text { the CNS\| technical skills was } \\
0.24 \text { times higher }(95 \% \mathrm{Cl}= \\
[0.08-0.69] ; \mathrm{p}<0.01) \\
\text { Ease of access to counseling } \\
\text { with a CNS } \mathrm{CN} \text { was } 7.93 \text { times } \\
\text { greater than counseling with } \\
\text { other professionals }(95 \% \mathrm{Cl}= \\
[1.05-59.82] ; \mathrm{p}=0.05)\end{array}$ \\
\hline $\begin{array}{l}\text { McCorkle R } \\
\text { et al. } \\
\mathbf{2 0 0 0}^{(32)} \text {, } \\
\text { USA, } \\
\text { Journal of } \\
\text { the American } \\
\text { Geriatrics } \\
\text { Society } \\
\text { Home Care }\end{array}$ & $\begin{array}{l}\text { Randomized } \\
\text { Controlled } \\
\text { Clinical Trial } \\
\text { (parallel) }\end{array}$ & $\begin{array}{l}\text { To compare the } \\
\text { survival time of } \\
\text { older adults post- } \\
\text { surgical patients } \\
\text { who received } \\
\text { a specialized } \\
\text { intervention } \\
\text { in home care } \\
\text { performed by } \\
\text { APN }{ }^{\ddagger} \text { with patients } \\
\text { who received } \\
\text { regular follow-up } \\
\text { in an outpatient } \\
\text { setting }\end{array}$ & 375 & $\mathrm{APN}^{\ddagger}$ & $\begin{array}{l}\text { Intervention: a } \\
\text { standardized protocol } \\
\text { that consisted of } \\
\text { standard assessment and } \\
\text { management of post- } \\
\text { surgical guidelines, doses } \\
\text { of instructional content } \\
\text { and contact hours, for } 4 \\
\text { weeks, which consisted } \\
\text { of } 3 \text { home visits and } \\
5 \text { telephone contacts } \\
\text { provided by APN. Both } \\
\text { patients and their families } \\
\text { received comprehensive } \\
\text { clinical assessments, } \\
\text { monitoring and teaching, } \\
\text { including skills training }\end{array}$ & $\begin{array}{l}\text { Among patients in advanced } \\
\text { stage, the survival time was } \\
\text { considerably better in the } \\
\text { intervention group } \\
\text { 2-year survival in cases } \\
\text { of intervention groups in } \\
\text { advanced stage was } 67 \% \\
\text { compared to } 40 \% \text { among } \\
\text { control cases } \\
\text { The relative risk of death in } \\
\text { the usual care group was } 2.04 \\
(95 \% \mathrm{Cl}=[1.33-3.12] ; \mathrm{p}=0.001)\end{array}$ \\
\hline $\begin{array}{l}\text { McCorkle R } \\
\text { et al. } \\
\mathbf{2 0 0 9}^{(33)} \text {, } \\
\text { USA, } \\
\text { Psycho- } \\
\text { oncology } \\
\text { Gynecological } \\
\text { Cancer }\end{array}$ & $\begin{array}{l}\text { Randomized } \\
\text { Controlled } \\
\text { Clinical Trial } \\
\text { (parallel) }\end{array}$ & $\begin{array}{l}\text { To assess health- } \\
\text { related quality } \\
\text { of life, complex } \\
\text { physical and } \\
\text { psychological } \\
\text { needs after surgery } \\
\text { and during } \\
\text { chemotherapy }\end{array}$ & 123 & $\mathrm{APN}^{\ddagger}$ & $\begin{array}{l}\text { Intervention: } 6 \text { months } \\
\text { of care by APN; the } \\
\text { main objective of the } \\
\text { intervention was to } \\
\text { help patients develop } \\
\text { and maintain self- } \\
\text { management skills in } \\
\text { the postoperative period } \\
\text { and facilitate their active } \\
\text { participation in decisions } \\
\text { that affect treatment. In } \\
\text { addition, women in high } \\
\text { distress were assessed } \\
\text { and monitored by } \\
\text { psychiatric APN } \\
\text { Control: they were } \\
\text { assigned to a research } \\
\text { assistant who used } \\
\text { a written manual } \\
\text { with information on } \\
\text { commonly experienced } \\
\text { symptoms and calls to } \\
\text { their oncologist when } \\
\text { needed } \\
\text { IG: } \mathrm{n}=63 \\
\mathrm{CG}^{+}: \mathrm{n}=60\end{array}$ & $\begin{array}{l}\text { The effect of the intervention } \\
\text { improves the patients' quality } \\
\text { of life } \\
\text { The rate of improvement on } \\
\text { the 'uncertainty scale' was } \\
\text { significantly higher for the } \\
\text { intervention group ( } p=0.0006 \text { ) } \\
\text { The psychiatric } \mathrm{APN}^{\ddagger} \\
\text { component was found to } \\
\text { significantly increase the rate } \\
\text { of improvement over time } \\
\text { for uncertainties ( } p=0.0181 \text { ), } \\
\text { distress symptoms ( } p<0.0001 \text { ), } \\
\text { mental }(p=0.0001) \text { and } \\
\text { physical }(p<0.0001 \text { ) health }\end{array}$ \\
\hline
\end{tabular}




\begin{tabular}{|c|c|c|c|c|c|c|}
\hline \multicolumn{3}{|c|}{ CHARACTERISTICS OF THE STUDY } & \multicolumn{2}{|c|}{ POPULATION } & \multicolumn{2}{|c|}{ INTERVENTION } \\
\hline $\begin{array}{l}\text { Reference, } \\
\text { Country, } \\
\text { Journal } \\
\text { Area / Scenario }\end{array}$ & $\begin{array}{l}\text { Design / } \\
\text { Method }\end{array}$ & Objective & Total $\mathrm{N}$ & $\begin{array}{c}\text { Education / } \\
\text { Degree }\end{array}$ & $\mathrm{IG}^{*} / \mathrm{CG}^{+}$ & Main results \\
\hline 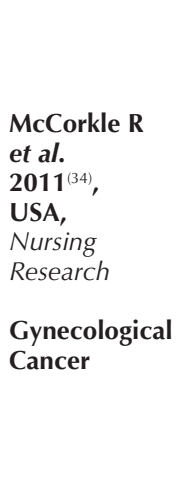 & $\begin{array}{l}\text { Randomized } \\
\text { Controlled } \\
\text { Clinical Trial } \\
\text { (parallel) }\end{array}$ & $\begin{array}{l}\text { To evaluate the } \\
\text { effectiveness of } \\
\text { interventions } \\
\text { provided by APN }{ }^{\ddagger} \\
\text { (oncological } \\
\text { and psychiatric) } \\
\text { in patients } \\
\text { undergoing } \\
\text { gynecological } \\
\text { surgery }\end{array}$ & 121 & $\mathrm{APN}^{\ddagger}$ & $\begin{array}{l}\text { Intervention: } 16 \\
\text { contacts made by APN } \\
\text { symptom management, } \\
\text { counseling, education, } \\
\text { direct nursing care, } \\
\text { resource coordination } \\
\text { and referrals. Control: } 9 \\
\text { contacts that included } \\
\text { instructions on using a } \\
\text { symptom management } \\
\text { toolkit and strategies } \\
\text { on how to manage } \\
\text { symptoms } \\
I^{*}: n=59 \\
\mathrm{CG}^{+}: \mathrm{n}=62\end{array}$ & $\begin{array}{l}\text { Patients who received the } \\
\text { APN intervention reported } \\
\text { fewer visits to their primary } \\
\text { care providers ( } \mathrm{p}=0.0003) \\
\text { Women who reported more } \\
\text { visits (control group) to their } \\
\text { primary care providers also } \\
\text { reported more depressive } \\
\text { symptoms } \\
\text { The intervention group visited } \\
\text { the emergency more often } \\
\text { because the APN }{ }^{\ddagger} \text { instructed } \\
\text { patients to go when they } \\
\text { recognized symptoms that } \\
\text { needed urgent care }(0.38 \mathrm{vs} \\
0.28 \text { in the control group) }\end{array}$ \\
\hline $\begin{array}{l}\text { Moore S et al. } \\
\mathbf{2 0 0 2}^{(35)} \text {, } \\
\text { England, } \\
\text { British } \\
\text { Medical Journal } \\
\text { Lung cancer }\end{array}$ & $\begin{array}{l}\text { Randomized } \\
\text { Controlled } \\
\text { Clinical Trial } \\
\text { (parallel) }\end{array}$ & $\begin{array}{l}\text { To evaluate the } \\
\text { effectiveness } \\
\text { of nurse } \\
\text { monitoring in } \\
\text { the management } \\
\text { of lung cancer } \\
\text { patients }\end{array}$ & 203 & CNS\| & $\begin{array}{l}\text { Conventional medical } \\
\text { follow-up vs Intervention: } \\
\text { CNS" led the follow-up } \\
\text { of outpatients } \\
I^{*}: n=100 \\
C^{+}: n=103\end{array}$ & $\begin{array}{l}\text { Patient acceptance of follow- } \\
\text { up conducted by CNS\| was } \\
\text { high: } 75 \% \text { ( } 203 / 271 \text { patients) } \\
\text { Intervention patients: had less } \\
\text { severe dyspnoea at } 3 \text { months } \\
\text { ( } p=0.03 \text { ) and had better scores } \\
\text { on emotional functioning } \\
\text { ( } p=0.03 \text { ), in addition to less } \\
\text { peripheral neuropathy ( } \mathrm{p}=0.05 \text { ) } \\
\text { at } 12 \text { months. They scored } \\
\text { significantly better in most } \\
\text { satisfaction subscales with } 3,6 \\
\text { and } 12 \text { months ( } \mathrm{p}<0.01 \text { for all } \\
\text { subscales at } 3 \text { months) } \\
\mathrm{CNS} \| \text { reported progression } \\
\text { of symptoms earlier than } \\
\text { physicians ( } \mathrm{p}=0.01) \\
\text { Patients who received follow- } \\
\text { up from CNS } \text { died more } \\
\text { at home rather than at the } \\
\text { hospital ( } \mathrm{p}=0.04), \text { attended } \\
\text { fewer consultations with a } \\
\text { physician during the first } 3 \\
\text { months ( } \mathrm{p}=0.004), \text { underwent } \\
\text { fewer radiographs during the } \\
\text { first } 6 \text { months ( } \mathrm{p}=0.04 \text { ) }\end{array}$ \\
\hline $\begin{array}{l}\text { Spoelstra SL } \\
\text { et al. } \\
\mathbf{2 0 1 7}^{(36)} \text {, } \\
\text { USA, } \\
\text { Clinical Journal } \\
\text { of Oncology } \\
\text { Nursing } \\
\text { Chemotherapy } \\
\text { Treatment }\end{array}$ & $\begin{array}{l}\text { Quasi- } \\
\text { experimental } \\
\text { study }\end{array}$ & $\begin{array}{l}\text { To refine an NP\$_ } \\
\text { led intervention } \\
\text { to promote } \\
\text { medication } \\
\text { adherence } \\
\text { and symptom } \\
\text { management in } \\
\text { newly prescribed } \\
\text { adults with cancer } \\
\text { (phase 1) } \\
\text { To explore } \\
\text { viability, } \\
\text { preliminary } \\
\text { efficacy with } \\
\text { adherence } \\
\text { and severity of } \\
\text { symptoms and } \\
\text { patient satisfaction } \\
\text { (phase 2) }\end{array}$ & 54 & $\begin{array}{l}\mathrm{APN}^{\ddagger} \\
\mathrm{NP}^{\S}\end{array}$ & $\begin{array}{l}\text { Usual care: instructions } \\
\text { on the oral antineoplastic } \\
\text { regimen, common } \\
\text { side effects, symptom } \\
\text { management, ways to } \\
\text { remember to take it, } \\
\text { medication safety and } \\
\text { when to contact the } \\
\text { provider vs } \\
\text { Intervention: a } 30 \text { min } \\
\text { face to face session } \\
\text { (week } 1 \text { ) with NP\$ at } \\
\text { the clinic, followed } \\
\text { by } 3 \text { weekly calls with } \\
\mathrm{NP}^{\S} \text { (weeks } 2,3 \text { and } \\
4 \text { ); the NP } \mathrm{NP}^{\S} \text { discussed } \\
\text { medication adherence, } \\
\text { symptom management } \\
\text { and safety tips, as well } \\
\text { as providing a toolkit } \\
\text { consisting of strategies to } \\
\text { support self-management } \\
\text { IG*: } \mathrm{n}=24 \\
\mathrm{CG}^{+}: \mathrm{n}=30\end{array}$ & $\begin{array}{l}\text { Weekly comparisons of } \\
\text { number and severity of } \\
\text { symptoms favored the } \\
\text { intervention group, with } \\
\text { significance reached at weeks } \\
2 \text { and } 5 \text { ( } \mathrm{p}=0.03-0.05) \\
\text { Most patients reported that } \\
\text { they were satisfied with the } \\
\text { content of the intervention, as } \\
\text { well as its usefulness }\end{array}$ \\
\hline
\end{tabular}




\begin{tabular}{|c|c|c|c|c|c|c|}
\hline \multicolumn{3}{|c|}{ CHARACTERISTICS OF THE STUDY } & \multicolumn{2}{|c|}{ POPULATION } & \multicolumn{2}{|c|}{ INTERVENTION } \\
\hline $\begin{array}{l}\text { Reference, } \\
\text { Country, } \\
\text { Journal } \\
\text { Area / Scenario }\end{array}$ & $\begin{array}{l}\text { Design / } \\
\text { Method }\end{array}$ & Objective & Total N & $\begin{array}{c}\text { Education / } \\
\text { Degree }\end{array}$ & $\mathrm{IG}^{*} / \mathrm{CG}^{+}$ & Main results \\
\hline $\begin{array}{l}\text { Traeger L et al. } \\
\text { 2015 }^{(37)} \text {, } \\
\text { USA, } \\
\text { Cancer } \\
\text { Chemotherapy } \\
\text { Treatment }\end{array}$ & $\begin{array}{l}\text { Randomized } \\
\text { Controlled } \\
\text { Clinical Trial } \\
\text { (parallel) }\end{array}$ & $\begin{array}{l}\text { To reduce } \\
\text { the burden of } \\
\text { patient-reported } \\
\text { symptoms, } \\
\text { facilitating } \\
\text { collaboration } \\
\text { between patients } \\
\text { and NP§ in } \\
\text { early symptom } \\
\text { management }\end{array}$ & 120 & NPs & $\begin{array}{l}\text { Standard treatment: } \\
\text { patients receive a clinical } \\
\text { visit on the first day of } \\
\text { each chemotherapy } \\
\text { administration cycle and } \\
\text { call the clinic as needed } \\
\text { vs Standard treatment } \\
+ \text { intervention (NP } \\
\text { proactive guidance and } \\
\text { support by phone during } \\
\text { the first } 2 \text { chemotherapy } \\
\text { administration cycles, } \\
\text { using clinical judgment } \\
\text { and patient-centered } \\
\text { intervention) } \\
I^{*}: n=60 \\
C^{+}: n=60\end{array}$ & $\begin{array}{l}\text { Satisfaction with the service } \\
\text { was relatively high } \\
\text { Regardless of the randomized } \\
\text { group, both the number of } \\
\text { symptoms }(p<0.001) \text { and the } \\
\text { symptom of distress }(p<0.001) \\
\text { increased } \\
\text { Satisfaction with care } \\
\text { increased ( } p=0.004) \text {, while } \\
\text { the probability of anxiety } \\
\text { symptoms decreased ( } p=0.02) \\
\text { Approximately } 93.3 \% \text { of } \\
\text { patients in the intervention } \\
\text { group reported that the } \\
\text { intervention was useful }(56 / 60 \\
\text { patients) }\end{array}$ \\
\hline $\begin{array}{l}\text { Visser A et al. } \\
\mathbf{2 0 1 5}^{(38)} \text { ' } \\
\text { Netherlands, } \\
\text { Clinical Nurse } \\
\text { Specialist } \\
\text { Journal } \\
\text { Breast cancer }\end{array}$ & $\begin{array}{l}\text { Randomized } \\
\text { Controlled } \\
\text { Clinical Trial } \\
\text { (parallel) }\end{array}$ & $\begin{array}{l}\text { To assess the } \\
\text { feasibility of breast } \\
\text { self-examination } \\
\text { education led } \\
\text { by CNS\| as part } \\
\text { of the BRCA } \\
\text { surveillance } \\
\text { To assess the } \\
\text { effects and } \\
\text { feasibility } \\
\text { of written } \\
\text { information } \\
\text { leaflets on breast } \\
\text { self-examination }\end{array}$ & 37 & CNS\| & $\begin{array}{l}\text { Women in both groups } \\
\text { were educated about } \\
\text { breast self-examination } \\
\text { by a CNS"l specially } \\
\text { trained during the annual } \\
\text { visit to the clinic } \\
\text { Intervention: they } \\
\text { received additional } \\
\text { written instructions, } \\
\text { in addition to self- } \\
\text { examination education } \\
I^{*}: n=15 \\
C^{+}: n=14\end{array}$ & $\begin{array}{l}62 \% \text { increased frequency of } \\
\text { breast self-examination after } \\
\text { receiving education } \\
\text { Significant overall increase } \\
\text { in frequency of breast self- } \\
\text { examination after education, } \\
\text { compared to frequency before } \\
\text { education - regardless of } \\
\text { receiving educational material } \\
\text { (p<0.001) } \\
\text { Overall patient satisfaction } \\
\text { with breast self-examination } \\
\text { education at the outpatient } \\
\text { clinic was } 4.3 \text { on a 5-point } \\
\text { scale } \\
\text { Patient satisfaction with written } \\
\text { educational materials scored } \\
4.2 \text { on a } 5 \text {-point scale } \\
\text { Trend towards a positive } \\
\text { association between patient } \\
\text { satisfaction with education on } \\
\text { breast self-examination led by } \\
\text { CNSII and the frequency of its } \\
\text { performance (p=0.055) }\end{array}$ \\
\hline
\end{tabular}

${ }^{*} \mathrm{IG}$ - Intervention Group; ${ }^{+} \mathrm{CG}$ - Control Group; ${ }^{\ddagger} \mathrm{APN}$ - Advanced Practice Nurse; ${ }^{\S} \mathrm{NP}$ - Nurse Practitioners; $" \mathrm{CNS}$ - Clinical Nurse Specialist; ` $\mathrm{BRCA}$ - Breast Cancer. $(n=12)$.

The main interventions identified in the studies, carried out by advanced practice nurses, were: educational guidelines $58.3 \%(27,29,32-34,36,38)$, in addition to telephone counseling $41.7 \% \%^{(28,30,32,36-37)}$, care coordination $25 \%^{(31,34-35)}$, symptom management and control $25 \%(31,34,36)$, clinical evaluation $16.7 \% \%^{(32,37)}$ and assistance clinical decision-making $16.7 \%^{(29,33)}$.

The main results and conclusions of the selected studies were identified: satisfaction in $36.4 \%^{(31,35-38)}$; improvement in pain control or other symptoms related to disease and/or treatment in $36.4 \%{ }^{(27,31,34-36)}$; improvement in the quality of life of cancer patients $27.3 \%{ }^{(27,29,31,33)}$; support in relation to psychological aspects, reducing patients' concerns about the disease and/or treatment, easing symptoms such as anxiety ${ }^{(37)}$ and improving $\operatorname{mood}^{(27)}$.

Two studies ${ }^{(27,32)}$ showed an improvement in the survival of cancer patients, when accompanied by an advanced practice nurse. Two other studies demonstrated the role of advanced practice nurses in carrying out the education and wishes of patients at the end of their lives, respecting preferences and choices in relation to the place of their death ${ }^{(35)}$, as well as demonstrating the possibility of shared decision after specific guidelines ${ }^{(29)}$.

Figure 2 details the risk of individual bias in selected randomized clinical trials. Two studies were classified as having low risk of bias in the seven domains assessed ${ }^{(32,35)}$. A total of five studies showed an uncertain and/or a high risk of selection bias due to weaknesses in the description of the strategy for generating the random sequence and concealing the allocation ${ }^{(27-30,38)}$. One of the studies ${ }^{(29)}$ had an uncertain risk of selection bias or high risk in all other risks of bias. Two studies ${ }^{(27,30)}$ showed the domain "blinding of outcome evaluators' with uncertain risk and two ${ }^{(29,33)}$ with high risk of bias, due to the poor description of the evaluation strategies. Four studies were classified as high risk of bias, because they had one or more compromised domains ${ }^{(28-29,33-34)}$. Four studies were classified as having an uncertain risk of bias ${ }^{(27-28,30,37)}$. 


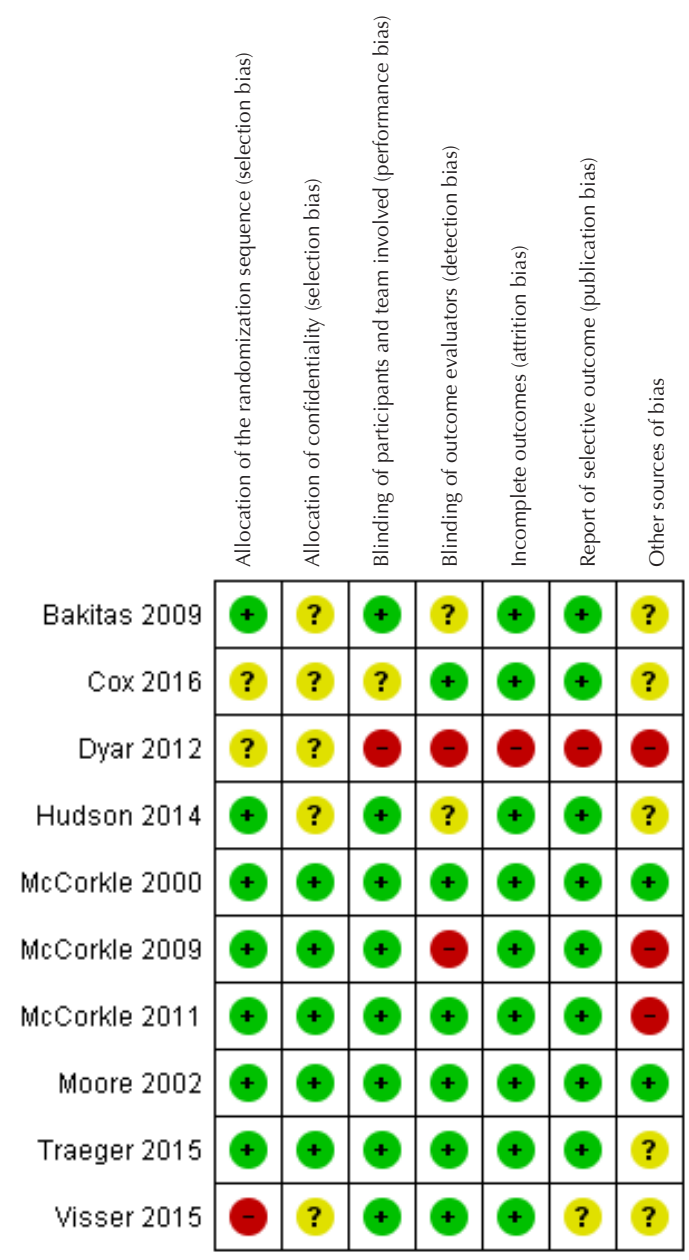

Figure 2 - Individual assessment of risk of bias in Randomized Controlled Trials according to RoB $1^{(25)}(\mathrm{n}=10)$.

Regarding the selected non-randomized studies (quasiexperiments), both ${ }^{(31,36)}$ had a low risk of bias in five domains and a moderate risk of bias in two domains. One study ${ }^{(31)}$ pointed to a moderate risk of bias in the domains measurement of results and bias in the selection of the described results, which are related to the post-intervention domains. This judgment was attributed due to possible systematic errors in measuring the result related to the intervention and the fact that the result measure may have been influenced by the knowledge of the received intervention. Another study ${ }^{(36)}$ had a moderate risk of bias in the confounding bias (pre-intervention) and bias in measuring outcome (post-intervention) domains. The judgment was attributed due to the lack of evidence in the control of the variables and co-interventions established, as well as the possibility that the outcome measure may have been influenced by the knowledge of the intervention received. In general, the studies were classified as having a moderate risk of bias. Figure 3 details the risk of individual bias in the two quasiexperimental studies.

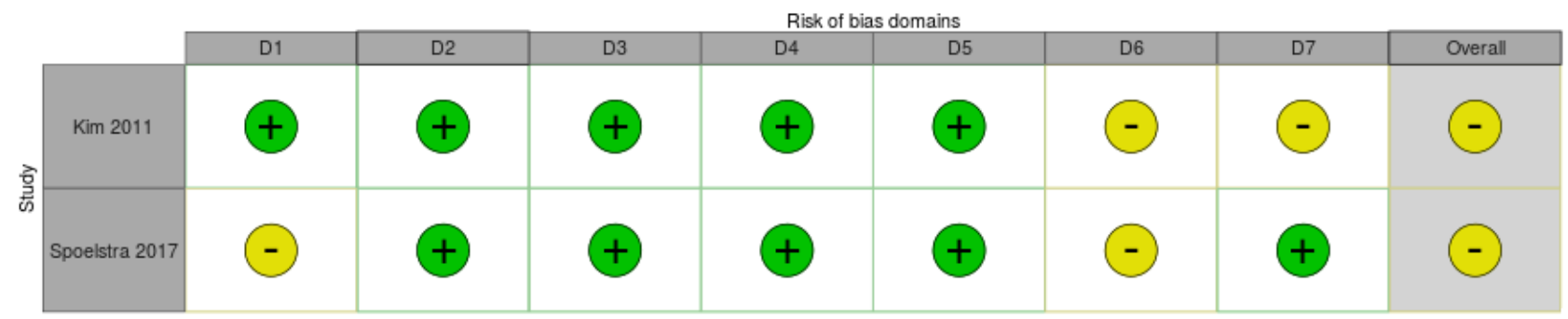

D1 - confounding bias (pre-intervention period);

D2 - selection bias of study participants (pre-intervention period);

D3 - classification bias of interventions (intervention period);

D4 - bias due to deviations from the proposed interventions (post-intervention period);

D5 - information bias - missing (post-intervention period);

D6 - outcome measurement bias (post-intervention period);

D7 - bias in selective reporting of outcomes (post-intervention period).

Figure 3 - Individual assessment of the risk of bias in quasi-experimental studies according to ROBINS- ${ }^{(26)}(n=02)$. 


\section{DISCUSSION}

Most of the studies selected in this review were conducted in the USA. It is believed that this data may be related to the origin of the APN, which in this country occurred in the 1970s. Since then, countries have gradually been structuring themselves for this practice, through some organizational changes and educational structures, as well as a definition on the professional performance and the skills needed to perform health care $^{(2)}$. It is known that for the implementation of the APN, it is necessary to present evidence that solidifies this change in the current health system, highlighting the conduction of these studies on the topic, mainly identified in the last 10 years.

Regarding the performance fields of advanced practice nurses in oncology, it is observed that they are concentrated in areas of greater performance and professional development (chemotherapy, palliative care) or incidence and prevalence of cancer (lung, breast and gynecological). It is noteworthy that, in general, the highest cancer incidence rates worldwide were observed in developed countries, in North America, Europe, Oceania, among others. In these places, there is a predominance of types of cancer associated with urbanization and development (lung, female breast, prostate) ${ }^{(10)}$, the priority areas for the expansion and clinical performance of the APN.

The title of advanced practice nurse in oncology is used to designate professionals who perform NP or CNS functions, who are educationally prepared with at least a master's degree in nursing, specialization in the related area and experience in the management of cancer patients. These professionals are inserted in all cancer treatment systems to guarantee specialized and cost-effective care. The complex needs of cancer care in the population, with the new modalities of treatments, innovations and technologies, create ample opportunities for growth in advanced practice nursing ${ }^{(20-21)}$, supporting the findings of this review in relation to the different settings of professional practice identified. Historically, the main role of advanced practice in oncology nursing was of the CNS, however, since the 1990s, the need to change the configurations of cancer care and the number of professionals has boosted the growth of NP oncology ${ }^{(20)}$.

Corroborating the findings of this review, a study ${ }^{(39)}$ presented as main results with cancer patients the management of symptoms, the improvement in the quality of life and the satisfaction of patients and their family. It is observed that the APN, in addition to contributing to a better quality of care, decreases health costs, and there is still evidence of high levels of satisfaction of the population in relation to the care provided $^{(6)}$. Systematic reviews ${ }^{(40-43)}$ on the performance of advanced practice nurses have shown results as good, or better, than their control groups, in line with the findings of some studies selected in this review.

Some researches have pointed out the following main results of care provided by advanced practice nurses: improvement in quality of life, increase in survival rates, improvement in the physical, functional and psychological well-being of patients, improvement in quality of disease treatment and health outcomes ${ }^{(44-48)}$, confirming the findings of this systematic review. It should be noted that advanced practice nurses provide effective care, maintaining satisfaction and better outcomes for patients and health institutions.

Some studies in this review identified advanced practice nurses as educators and care coordinators, professionals who work collaboratively with patients and interprofessional teams, with the aim of promoting care and easing the transition process from diagnosis to the end of life. Therefore, it is relevant to highlight their role within the health team and emphasize that for successful collaboration, effective communication and good interpersonal relationships are necessary. Advanced practice nurses support the health team in identifying and addressing the physical, emotional and social needs of these patients and their families, contributing to different stages of care in the diverse oncology scenarios.

This expanded role of the advanced practice of caring for cancer patients across the care continuum, as an indispensable part of a multidisciplinary team, can serve as a model for the implementation of APN across the country. However, it is noted that for an expanded clinical practice in oncology, it is essential that advanced practice nurses have specific knowledge and skills in a wide variety of study areas, requiring guidelines for professional training and clinical practice, as well as regulations for the development of their role in our country.

A study ${ }^{(38)}$ in this review demonstrated the importance of education led by the CNS as part of monitoring patients with BRCA mutations. Thus, the nurses' role in oncogenetics is emphasized as an integral member and reference of the interdisciplinary team, with regard to health care based on genomics, which incorporate diagnosis, prevention and treatment ${ }^{(49)}$. Advanced practice nurses with knowledge in genetics qualifies the care and access of people at risk or of patients diagnosed with cancer. It is through oncogenetic counseling that the APN acts in an educational manner, provides support to patients and family members, interprets test results and/or diagnostic tests, among others ${ }^{(50)}$.

A Brazilian study, on the other hand, developed in a genetic counseling service, showed the need for professional interventions with this type of patients, with the development of health education activities being one of the essential elements for nursing care in oncogenetics ${ }^{(51)}$.

There is a body of international evidence that points to solutions in health systems, with the expansion of access, as well as evidence of improvements in patients' clinical outcomes, with the guarantee of safety and quality of care ${ }^{(7)}$. Thus, it is emphasized that there is a worldwide interest in the implementation of advanced practice nursing as an essential vehicle for innovation and reforms in health, with the aim of providing more effective and sustainable care models ${ }^{(52)}$.

This review included studies that showed significant results in the performance of advanced practice nurses, individually. As limitations, one points out: the databases, due to the fact that it does not include studies indexed in other databases, as well as it was restricted to articles published in full, which portrays part of the universe of studies; the significant 
heterogeneity of the studies included with regard mainly to methodological differences, such as heterogeneous clinical area and/or specialties, profile of participants, characteristics of interventions and clinical outcomes, which made it impossible to perform the meta-analysis of the data, as well as a broader comparison and synthesis of data; another limitation concerns the fact that different interventions are evaluated in different contexts of cancer treatment (chemotherapy, palliative, among others), analyzing different tumor types, making the studies heterogeneous and quantitative analyzes unfeasible.

In addition, the absence of a control group and the short follow-up time may have impaired the measurement of outcomes in some studies. It is also noted the weakness of randomized clinical trials, mainly in relation to their designs and randomization, providing greater risks of bias. Thus, it is suggested to carry out experimental studies with higher methodological quality, in order to seek evidence of professional training and prove the clinical performance of APN in the most diverse scenarios of oncology.

\section{CONCLUSION}

The studies selected in this review demonstrated the value of APN in the oncology field, through differentiated clinical training and advanced professional performance. Most studies showed clinical results through educational interventions carried out by these nurses. In some of the studies, better clinical outcomes related to the control and management of symptoms, quality of life and survival were identified, with the guarantee of the satisfaction of the cancer patient, when they are cared by advanced practice nurses.

\section{RESUMO}

Objetivo: Buscar evidências da formação de enfermeiros de prática avançada, mediante a atuação clínica e os cuidados de enfermagem com pacientes oncológicos. Método: Revisão sistemática, com busca nas bases de dados: MEDLINE-PubMed, Lilacs, Web of Science, Scopus, Cinahl e Cochrane CENTRAL. Realizou-se também uma busca manual na lista de referências e no Google Scholar. Para a avaliação da qualidade metodológica dos estudos utilizaram-se as ferramentas: Cochrane Collaboration Risk of Bias Tool (RoB 1) para os ensaios clínicos randomizados e Risk of Bias in Non-randomised Studies of Interventions (ROBINS-I) para os quase-experimentais. Resultados: Foram identificados 12 estudos experimentais. A principal intervenção identificada nos estudos foi a orientação educacional. Os estudos apresentaram melhora no controle de dor ou outros sintomas relacionados a doença e/ou tratamento, satisfação e melhora na qualidade de vida dos pacientes com câncer. Conclusão: Observa-se que há estudos que demonstram o valor da enfermagem de prática avançada no cenário da oncologia, mediante uma formação clínica diferenciada e atuação profissional avançada. Número de registro da revisão sistemática: CRD42018098906.

\section{DESCRITORES}

Enfermagem Oncológica; Prática Avançada de Enfermagem; Resultado do Tratamento; Enfermagem Baseada em Evidências; Revisão.

\section{RESUMEN}

Objetivo: Buscar evidencias de la capacitación de los enfermeros de práctica avanzada mediante la actuación clínica y los cuidados de enfermería de pacientes oncológicos. Método: Se trata de una revisão sistemática, con búsqueda realizada en las bases de datos: MEDLINE-PubMed, Lilacs, Web of Science, Scopus, Cinahl y Cocbrane CENTRAL. Se llevó a cabo, también, una búsqueda manual en la lista de referencias y en el Google Scholar. Para evaluar la calidad metodológica de los estudios se utilizaron las herramientas: Cochrane Collaboration Risk of Bias Tool (RoB 1) para los ensayos clínicos randomizados y el Risk of Bias in Non-randomised Studies of Interventions (ROBINS-I) para los cuasi experimentales. Resultados: Se identificaron doce estudios experimentales. La principal intervención encontrada fue la orientación educativa. Los estudios mostraron una mejora en el control del dolor u otros síntomas relacionados con la enfermedad y/o el tratamiento, satisfacción y mejora de la calidad de vida de los pacientes con cáncer. Conclusión: Se observa que hay estudios que demuestran el valor de la enfermería de práctica avanzada en el escenario oncológico, a través de una formación clínica diferenciada y una actuación profesional avanzada. Número de registro de la revisão sistemática: CRD42018098906.

\section{DESCRIPTORES}

Enfermería Oncológica; Enfermería de Práctica Avanzada; Resultado del Tratamiento; Enfermería Basada en la Evidencia; Revisión.

\section{REFERENCES}

1. Miranda Neto MV, Rewa T, Leonello VM, Oliveira MAC. Advanced practice nursing: a possibility for primary health care? Rev Bras Enferm. 2018;71 Suppl 1:716-21. doi: 10.1590/0034-7167-2017-0672

2. International Council of Nurses. Nurse practitioner/advanced practice nursing network country profiles [Internet]. Helsinki:: ICN; 2014 [cited 2018 May 30]. Available from: http://international.aanp.org/content/docs/countryprofiles2014.pdf

3. Olímpio JA, Araújo JN, Pitombeira DO, Enders BC, Sonenberg A, Vitor AF. Advanced practice nursing: a concept analysis. Acta Paul Enferm. 2018;31(6):674-80. doi: 10.1590/1982-0194201800092

4. International Council of Nurses. Guidelines on advanced practice nursing [Internet]. Helsinki: ICN; 2020 [cited 2020 July 20 ]. Available from: https://www.icn.ch/system/files/documents/2020-04/ICN_APN\%20Report_EN_WEB.pdf

5. Zug KE, Cassiani SHB, Pulcini J, Bassalobre Garcia A, Aguirre-Boza F, Park J. Advanced practice nursing in Latin America and the Caribbean: regulation, education and practice. Rev Latino Am Enfermagem. 2016;24:e2807. doi: 10.1590/1518-8345.1615.2807

6. Bryant-Lukosius D, Martin-Misener R. ICN Policy Brief. Advanced practice nursing: an essential component of country level human resources for health [Internet]. Geneva: ICN; 2016 [cited 2018 June 03]. Available from: https://www.who.int/workforcealliance/ knowledge/resources/ICN_PolicyBrief6AdvancedPracticeNursing.pdf

7. Bryant-Lukosius D, Valaitis R, Martin-Misener R, Donald F, Peña L, Brousseau L. Advanced practice nursing: a strategy for achieving universal health coverage and universal access to health. Rev Latino Am Enfermagem. 2017;25:e2826. doi: 10.1590/1518-8345.1677.2826 
8. Organização Pan-Americana da Saúde. Ampliação do papel dos enfermeiros na atenção primária à saúde [Internet]. Washington: OPAS; 2018 [citado 2019 jul. 12]. Disponível em: http://iris.paho.org/xmlui/handle/123456789/34960

9. Bezerril MS, Chiavone FB, Mariz CM, Sonenberg A, Enders BC, Santos VE. Advanced practice nursing in Latin America and the Caribbean: context analysis. Acta Paul Enferm. 2018;31(6):636-43. doi: 10.1590/1982-0194201800087

10. Bray F, Ferlay J, Soerjomataram I, Siegel RL, Torre LA, Jemal A. Global cancer statistics 2018: GLOBOCAN estimates of incidence and mortality worldwide for 36 cancers in 185 countries. CA Cancer J Clin. 2018;68(6):394-424. doi: https://10.3322/caac.21492

11. Instituto Nacional de Câncer José Alencar Gomes da Silva. Incidência de câncer no Brasil: estimativa 2020 [Internet]. Rio de Janeiro: INCA; 2019 [citado 2019 jul. 18]. Disponível em: https://www.inca.gov.br/sites/ufu.sti.inca.local/files/media/document/estimativa-2020incidencia-de-cancer-no-brasil.pdf

12. Wujcik D. Scientific advances shaping the future roles of oncology nurses. Semin Oncol Nurs. 2016;32(2):87-98. doi: 10.1016/j. soncn.2016.02.003

13. Hinkel JM, Vandergrift JL, Perkel SJ, Waldinger MB, Levy W, Steward FM. Practice and productivity of physician assistants and nurse practitioners in outpatient oncology clinics at National Comprehensive Cancer Network institutions. J Oncol Pract. 2010;6(4):182-7. doi: 10.1200/JOP.777001

14. Nevidjon B, Rieger P, Miller Murphy C, Rosenzweig MQ, McCorkle MR, Baileys K. Filling the gap: development of the oncology nurse practitioner workforce. J Oncol Pract. 2010;6(1):2-6. doi: 10.1200/JOP.091072

15. Towle EL, Barr TR, Hanley A, Kosty M, Williams S, Goldstein MA. Results of the ASCO study of collaborative practice arrangements. J Oncol Pract. 2011;7(5):278-82. doi: 10.1200/JOP.2011.000385

16. McCorkle R, Engelking C, Lazenby M, Davies MJ, Ercolano E, Lyons CA. Perceptions of roles, practice patterns, and professional growth opportunities: broadening the scope of advanced practice in oncology. Clin J Oncol Nurs. 2012;16(4):382-7. doi: 10.1188/12. CJON.382-387

17. Institute of Medicine. The future of nursing: leading change, advancing health [Internet]. Washington: National Academies; 2011 [cited 2018 May 30]. Available from: https://www.ncbi.nlm.nih.gov/books/NBK209880/pdf/Bookshelf_NBK209880.pdf

18. Brown CG. Commentary: new findings substantiate the successful use of nurse practitioners and physician assistants in collaborative practice models. J Oncol Pract. 2011;7(5):283-34. doi: 10.1200/JOP.2011.000387

19. Cunningham RS. Advanced practice nursing outcomes: a review of selected empirical literature. Oncol Nurs Forum. 2004;31(2):219-32. doi: 10.1188/04.ONF.219-232

20. Lopes-Júnior LC, Olson K, Bomfim EO, Pereira-da-Silva G, Nascimento LC, Lima RAG. Translational research and symptom management in oncology nursing. Br J Nurs. 2016;25(10):S12-S21. doi: 10.12968/bjon.2016.25.10.S12

21. Oncology Nursing Society. Oncology nurse practitioner competencies. Pittsburgh: ONS; 2019.

22. Moher D, Liberati A, Tetzlaff J, Altman DG, PRISMA Group. Preferred reporting items for systematic reviews and meta-analyses: the PRISMA statement. PLoS Med. 2009;6(7):e1000097. doi: 10.1371/journal.pmed.1000097

23. National Institute for Health Research. International prospective register of systematic reviews (PROSPERO) [Internet]. London; 2018 [cited 2018 July 25]. Available from: https://www.crd.york.ac.uk/prospero/display_record.php?RecordID=98906

24. Methley AM, Campbell S, Chew-Graham C, McNally R, Cheraghi-Sohi S. PICOS and SPIDER: a comparison study of specificity and sensitivity in three search tools for qualitative systematic reviews. BMC Health Serv Res. 2014;14(1):579. doi: 10.1186/s12913-014-0579-0

25. Higgins J, Green S, editors. Cochrane handbook for systematic reviews of interventions version 5.1.0 [Internet]. Chichester: John Wiley \& Sons; 2011 [cited 2019 July 12]. Available from: https://training.cochrane.org/handbook

26. Sterne JA, Hernán MA, Reeves BC. ROBINS-I: a tool for assessing risk of bias in non-randomised studies of interventions. BMJ. 2016;355:i4919. doi: 10.1136/bmj.i4919

27. Bakitas M, Lyons K, Hegel M, Balan S, Brokaw F, Seville J, et al. Effects of a palliative care intervention on clinical outcomes in patients with advanced cancer: the project ENABLE II randomized controlled trial. JAMA. 2009;302(7):741-9. doi: 10.1001/jama.2009.1198

28. Cox CL, Andersen MR, Santucci AK, Robison LL, Hudson MM. Increasing cardiomyopathy screening in childhood cancer survivors: a cost analysis of advanced practice nurse phone counseling. Oncol Nurs Forum. 2016;43(6):E242-E250. doi: 10.1188/16.ONF.E242-E250

29. Dyar S, Lesperance M, Shannon R, Sloan J, Colon-Otero G. A nurse practitioner directed intervention improves the quality of life of patients with metastatic cancer: results of a randomized pilot study. J Palliat Med. 2012;15(8):890-5. doi: 10.1089/jpm.2012.0014

30. Hudson MM, Leisenring W, Stratton KK, Tinner N, Steen BD, Ogg S, et al. Increasing cardiomyopathy screening in at-risk adult survivors of pediatric malignancies: a randomized controlled trial. J Clin Oncol. 2014;32(35):3974-U266. doi: 10.1200/JCO.2014.57.3493

31. Kim MY. Effects of oncology clinical nurse specialists' interventions on nursing-sensitive outcomes in South Korea. Clin J Oncol Nurs. 2011;15(5):E66-74. doi: 10.1188/11.ONF.E66-E74.

32. McCorkle R, Strumpf N, Nuamah I, Adler D, Cooley M, Jepson C, et al. A specialized home care intervention improves survival among older post-surgical cancer patients. J Am Geriatr Soc. 2000;48(12):1707-13. doi: 10.1111/j.1532-5415.2000.tb03886.x

33. McCorkle R, Dowd M, Ercolano E, Schulman-Green D, Williams A, Siefert M, et al. Effects of a nursing intervention on quality of life outcomes in post-surgical women with gynecological cancers. Psycho-Oncology. 2009;18(1):62-70. doi: 10.1002/pon.1365

34. McCorkle R, Jeon S, Ercolano E, Schwartz P. Healthcare utilization in women after abdominal surgery for ovarian cancer. Nurs Res. 2011;60(1):47-57. doi: 10.1097/NNR.0b013e3181ff77e4

35. Moore S, Corner J, Haviland J, Wells M, Salmon E, Normand C, et al. Nurse led follow up and conventional medical follow up in management of patients with lung cancer: randomised trial. BMJ. 2002;325(7373):1145. doi: 10.1136/bmj.325.7373.1145. 
36. Spoelstra SL, Sikorskii A, Majumder A, Burhenn PS, Schueller M, Given B. Oral anticancer agents: an intervention to promote medication adherence and symptom management. Clin J Oncol Nurs. 2017;21(2):157-60. doi: 10.1188/17.CJON.157-160

37. Traeger L, McDonnell TM, McCarty CE, Greer JA, El-Jawahri A, Temel JS. Nursing intervention to enhance outpatient chemotherapy symptom management: patient-reported outcomes of a randomized controlled trial. Cancer. 2015;121(21):3905-13. doi: 10.1002/ cncr.29585

38. Visser A, Bos WC, Prins JB, Hoogerbrugge N, van Laarhoven HW. Breast self-examination education for BRCA mutation carriers by clinical nurse specialists. Clin Nurse Spec. 2015;29(3):E1-7. doi: 10.1097/NUR.0000000000000118

39. Lynch MP, Cope DG, Murphy-Ende K. Advanced practice issues: results of the ONS advanced practice nursing survey. Oncol Nurs Forum. 2001;28(10):1521-30.

40. Donald F, Martin-Misener R, Carter N, Donald E, Kaasalainen S, Wickson-Griffiths A, et al. A systematic review of the effectiveness of advanced practice nurses in longterm care. J Adv Nurs. 2013;69(10):2148-61. doi: 10.1111/jan.12140

41. Donald F, Kilpatrick K, Reid K, Carter N, Martin-Misener, R, Bryant-Lukosius D, et al. A systematic review of the cost-effectiveness of clinical nurse specialists and nurse practitioners: what is the quality of the evidence? Nurs Res Pract. 2014;2014:896587. doi: $10.1155 / 2014 / 896587$

42. Morilla-Herrera JC, Garcia-Mayor S, Martín-Santos FJ, Kaknani Uttumchandani S, Leon Campos Á, Caro Bautista J, et al. A systematic review of the effectiveness and roles of advanced practice nursing in older people. Int J Nurs Stud. 2016;53:290-307. doi: 10.1016/j. ijnurstu.2015.10.010

43. Newhouse RP, Stanik-Hutt J, White KM, Johantgen M, Bass EB, Zangaro G, et al. Advanced practice nurse outcomes 1990-2008: a systematic review. Nurs Econ. 2011;29(5):230-50.

44. Bryant-Lukosius D, Carter N, Reid K., Donald F, Martin-Misener R, Kilpatrick K, et al. The clinical effectiveness and cost-effectiveness of clinical nurse specialist-led hospital to home transitional care: a systematic review. J Eval Clin Pract. 2015;21(5):763-81. doi: 10.1111/jep.12401

45. Bryant-Lukosius D, Cosby R, Bakker D, Earle C, Burkoski V. Practice guideline on the effective use of advanced practice nurses in the delivery of adult cancer services in Ontario. Toronto: Cancer Care Ontario; 2015.

46. Canadian Centre for Advanced Practice Nursing Research (CCAPNR). The clinical nurse specialist: getting a good return on healthcare investment. Hamilton: McMaster University; 2012.

47. Kilpatrick K, Reid K, Carter N, Donald F, Bryant-Lukosius D, Martin-Misener R, et al. A systematic review of the cost effectiveness of clinical nurse specialists and nurse practitioners in inpatient roles. Nurs Leadersh (Tor Ont). 2015;28(3):56-76. doi: 10.1155/2014/896587

48. Kilpatrick K, Kaasalainen S, Donald F, Reid K, Carter N, Bryant-Lukosius D, et al. The effectiveness and cost effectiveness of clinical nurse specialists in outpatient roles: a systematic review. J Eval Clin Pract. 2014;20(6):1106-23. doi: 10.1111/jep.12219

49. Flória-Santos M, Santos EMM, Nascimento LC, Pereira-da-Silva G, Ferreira BR, Miranda DO, et al. Oncology nursing practice from the perspective of genetics and genomics. Texto Contexto Enferm. 2013;22(2):526-33. doi: 10.1590/S0104-07072013000200031

50. Kerber AS, Ledbetter NJ. Scope and standards defining the advanced practice role in genetics. Clin J Oncol Nurs. 2017;21(3):309-13. doi: 10.1188/17.CJON.309-313

51. Silva TBC, MacDonald DJ, Ferraz VEF, Nascimento LC, Santos CB, Lopes-Júnior LC, et al. Perception of cancer causes and risk, family history and preventive behaviors of users in oncogenetic counseling. Rev Esc Enferm USP. 2013;47(2):377-84. doi: 10.1590/S008062342013000200015

52. Bryant-Lukosius D. Back to the future: advancing the global evolution of advanced practice nursing. Helsinki: International Council of Nurses; 2014.

Financial support:

This study was supported by the Coordenação de Aperfeiçoamento de Pessoal de Nível Superior - Brazil (CAPES) - Financing Code 001. 